\title{
Whole blood-based measurement of SARS-CoV-2-specific T cell responses reveals asymptomatic infection and vaccine efficacy in healthy subjects and patients with solid organ cancers
}

Martin J. Scurr ${ }^{1,2}$, Wioleta M. Zelek ${ }^{3,4}$, George Lippiatt ${ }^{2}$, Michelle Somerville ${ }^{1}$, Stephanie E. A. Burnell ${ }^{1}$, Lorenzo Capitani' ${ }^{1}$, Kate Davies ${ }^{5}$, Helen Lawton ${ }^{5}$, Thomas Tozer $^{6}$, Tara Rees ${ }^{6}$, Kerry Roberts ${ }^{6}$, Mererid Evans ${ }^{7}$, Amanda Jackson ${ }^{7}$, Charlotte Young $^{7}$, Lucy Fairclough ${ }^{8}$, Mark Wills ${ }^{9}$, Andrew D. Westwell ${ }^{10}$, B. Paul Morgan ${ }^{3,4}$, Awen Gallimore ${ }^{\star 1,3 \S}$ and Andrew Godkin*1,3,6§

1 Division of Infection \& Immunity, School of Medicine, Cardiff University, Cardiff, UK.

2 ImmunoServ Ltd., Cardiff, UK

${ }^{3}$ Systems Immunity University Research Institute, School of Medicine, Cardiff University, Cardiff, UK.

4 UK Dementia Research Institute Cardiff, Cardiff University, Cardiff, UK.

${ }^{5}$ Radyr Medical Centre, Cardiff, UK.

${ }^{6}$ Dept. of Gastroenterology \& Hepatology, University Hospital of Wales, Heath Park, Cardiff, UK.

7 Velindre Cancer Centre, Cardiff, UK.

8 School of Life Sciences, University of Nottingham, Nottingham, UK.

${ }^{9}$ Department of Medicine, Addenbrookes Hospital, University of Cambridge, Cambridge, UK.

10 School of Pharmacy and Pharmaceutical Sciences, Cardiff University, Cardiff, UK.

${ }^{*}$ Corresponding Authors:

Prof Andrew Godkin

Division of Infection and Immunity

Henry Wellcome Building

Health Park

Cardiff

CF14 4XN

Email: godkinaj@cardiff.ac.uk

Authorship note: (\$) Aw.G and An.G contributed equally to this work.

Funding: This work was funded by two UKRI COVID-19 National Core Study Immunity programmes ('Coordinating COVID-19 asymptomatic testing programmes in university settings: providing insight on acquired immunity across the student population', and 'SARS-CoV-2 Optimal Cellular Assays'). Additional funding was provided by the MRC, as part of the UK Coronavirus Immunology Consortium, and Cancer Research Wales.

Running title: SARS-CoV-2 T cell responses to measure vaccine efficacy

Conflict of interest: MJS is a founder of and holds equity in ImmunoServ Ltd. All other authors declare no conflicts of interest. 
medRxiv preprint doi: https://doi.org/10.1101/2021.06.02.21258218; this version posted June 3, 2021. The copyright holder for this preprint (which was not certified by peer review) is the author/funder, who has granted medRxiv a license to display the preprint in perpetuity.

\section{Abstract}

Accurate assessment of SARS-CoV-2 immunity in the population is critical to evaluating vaccine efficacy and devising public health policies. Whilst the exact nature of effective immunity remains incompletely defined, SARS-CoV-2-specific T cell responses are a critical feature of the immune response that will likely form a key correlate of protection against COVID-19. Here, we developed and optimised a highthroughput whole blood-based assay to determine the T cell response associated with prior SARS-CoV-2 infection and/or vaccination amongst 156 healthy donors and 67 cancer patients. Following overnight in vitro stimulation with SARS-CoV-2-specific peptides, blood plasma samples were harvested and analysed for $T_{H} 1$-type effector cytokines (IFN- $\gamma$ and IL-2). Amongst healthy donors, highly significant differential IFN$\gamma^{+} /$IL-2+ SARS-CoV-2-specific T cell responses were seen amongst vaccinated or previously infected COVID-19-positive individuals in comparison to unknown/naïve individuals $(P<0.0001)$. IL-2 production from $T$ cells in response to SARS-CoV-2 derived antigens was a highly predictive diagnostic assay $(P<0.0001 ; 96.0 \%$ sensitivity, 93.9\% specificity); measurement of IFN- $\gamma^{+}$SARS-CoV-2 specific T cell responses was equally effective at identifying asymptomatic (antibody and $\mathrm{T}$ cell positive) participants. A single dose of COVID-19 vaccine induced IFN- $\gamma$ and/or IL-2 SARS-CoV-2-specific T cell responses in 28/29 (96.6\%) of healthy donors, reducing significantly to $27 / 56(48.2 \%)$ when measured in cancer patients $(P=0.0003)$. Overall, this cost-effective standardisable test ensures accurate and comparable assessments of SARS-CoV-2-specific $\mathrm{T}$ cell responses amenable to widespread population immunity testing. 
medRxiv preprint doi: https://doi.org/10.1101/2021.06.02.21258218; this version posted June 3, 2021. The copyright holder for this preprint (which was not certified by peer review) is the author/funder, who has granted medRxiv a license to display the preprint in perpetuity. It is made available under a CC-BY-NC-ND 4.0 International license.

\section{Background}

As the COVID-19 pandemic continues, there is an increasing focus on understanding how adaptive immune responses generated from severe acute respiratory syndrome coronavirus 2 (SARS-CoV-2) infection and/or vaccination provide protection from future infection. Although the exact determinants of effective immunity from reinfection with SARS-CoV-2 remain to be deciphered, multiple recent studies have revealed that virus-specific $\mathrm{T}$ cell responses develop in nearly all individuals with confirmed SARS-CoV-2 infection (1-4), with responses persisting for at least six months post-infection (5). Traditional means of assessing viral antigen-specific $\mathrm{T}$ cell responses utilise flow cytometry or ELISpot-based readouts; however, neither approach is standardisable across multiple laboratories, cost-effective, or amenable to high-throughput processing, thus precluding their use for larger scale population immunity screen. In addition, current commercially available immunoassays that detect cellular immune responses to SARS-CoV-2 solely measure IFN- $\gamma$ released by

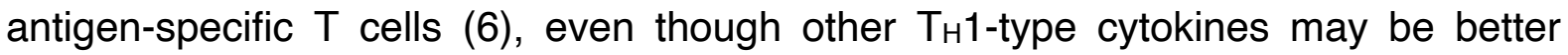
indicators of anti-viral response (5). To overcome these limitations, existing whole blood-based in vitro immunodiagnostics, such as those used for measuring Mycobacterium tuberculosis-specific T cell responses (7), can be adapted to measure virus-specific $\mathrm{T}$ cell responses in a high-throughput, standardisable manner. Specifically, this T cell immunoassay measures cytokines in the plasma released by antigen-specific $T$ cells following stimulation with specific peptides spanning antigenic regions of the pathogen. This approach is gaining recognition as a potentially powerful diagnostic tool for managing the COVID-19 pandemic (8-10).

Monitoring immunological responses to SARS-CoV-2 is of particular importance amongst the elderly and immunosuppressed, given the significantly higher mortality rates observed in these groups (11). Recent studies have associated higher rates of COVID-19 morbidity and mortality with sub-optimal adaptive immune responses (12). The incidence of cancer is also increased in the elderly where a declining adaptive immune system, as well as age-associated inflammation, are factors in disease progression. Given that influenza vaccines induce weaker immune responses in the elderly and in cancer patients $(13,14)$, measuring adaptive immune responses to SARS-CoV-2 in vaccinated individuals belonging to these groups is important. Indeed, early indications suggest that cancer patients, in particular those 
medRxiv preprint doi: https://doi.org/10.1101/2021.06.02.21258218; this version posted June 3, 2021. The copyright holder for this preprint

on active treatments such as chemotherapy, were significantly less likely to mount antibody and T cell responses to the Pfizer-BioNTech SARS-CoV-2 mRNA vaccine, (15).

Here, we adapted and optimised a widely utilised in vitro whole blood stimulation assay to determine the presence of SARS-CoV-2-specific TH1-type (IFN- $\gamma$ / IL-2) cellular immune responses in healthy donors, to assess $\mathrm{T}$ cell responses generated from prior infection, whether the participant was symptomatic or not, and as a readout of vaccine efficacy amongst healthy donors and cancer patients. We demonstrate high sensitivity and specificity of this assay to identify or exclude prior SARS-CoV-2 infection and/or successful COVID-19 vaccination. Going forward, it is imperative to utilise such tests to understand the precise contribution of $\mathrm{T}$ cell responses with regards to long-term immunity to SARS-CoV-2 infection, in particular amongst immunocompromised individuals. 
medRxiv preprint doi: https://doi.org/10.1101/2021.06.02.21258218; this version posted June 3, 2021. The copyright holder for this preprint (which was not certified by peer review) is the author/funder, who has granted medRxiv a license to display the preprint in perpetuity.

\section{Methods}

Study cohorts

Participants were recruited to this research project between February-April 2021. A healthy donor cohort $(n=156)$ comprised university staff and students attending Cardiff University's COVID-19 Screening Service or members of the public attending a Cardiff-based GP practice. All participants were otherwise healthy and did not report taking any current immunosuppressive treatment. In addition, patients with a range of solid-organ cancers $(n=67)$ were recruited from Velindre Cancer Centre prior to receiving their first COVID-19 vaccine (see Table 1 for basic characteristics). All participants were stratified based on self-reported and/or laboratory evidence of a prior SARS-CoV-2 infection. Participants reporting no prior positive test were defined as 'unknown/naïve'. To measure immunological responses generated to COVID-19 vaccination, baseline blood samples were taken immediately preceding the first dose; an additional post-vaccination blood sample was taken 3-6 weeks later. Only participants donating a blood sample both pre- and post-vaccination were included in the analyses. All vaccinated participants received either Pfizer (BNT162b2) mRNA vaccine or AstraZeneca (ChAdOx1 nCoV-19) vaccine.

This study received ethical approval from the Wales Cancer Bank (WCB No. 21/004), the Newcastle \& North Tyneside 2 Research Ethics Committee (IRAS ID: 294246) and Cardiff University School of Medicine Research Ethics Committee (SREC reference: SMREC 21/01). All participants gave written, informed consent prior to inclusion.

\section{Peptides}

All SARS-CoV-2 peptides were dissolved according to manufacturer's instructions (Miltenyi Biotec). A single SARS-CoV-2-specific S-/NP-/M-combined peptide pool was created, comprising mainly 15-mer sequences with 11-amino acid overlap, covering the entire spike (S1 and S2) protein (S), nucleocapsid phosphoprotein (NP) and membrane glycoprotein (M). All peptides were used at a final concentration of 0.5 $\mu \mathrm{g} / \mathrm{ml}$.

\section{Stimulation}


medRxiv preprint doi: https://doi.org/10.1101/2021.06.02.21258218; this version posted June 3, 2021. The copyright holder for this preprint

A single $6 \mathrm{ml}$ or $10 \mathrm{ml}$ sodium heparin vacutainer (BD) tube of venous blood was collected from each participant and processed in the laboratory within 12 hours of blood draw. Whole blood samples were aliquoted into microcentrifuge tubes (Thermo Scientific) containing pre-aliquoted peptides, alongside additional tubes containing phytohaemagglutinin (Sigma) (positive control) or nothing (negative control). Samples were incubated at $37^{\circ} \mathrm{C}$ for $20-24$ hours. Tubes were then centrifuged at $3000 \mathrm{~g}$ for 2 minutes before harvesting plasma from the top of each blood sample. Plasma samples were stored at $-20^{\circ} \mathrm{C}$ for up to one month prior to running cytokine detection assays.

\section{Detection of anti-SARS-CoV-2 RBD IgG Antibodies}

An in-house direct ELISA was developed as previously described (16-19), with some modifications. Maxisorp (Nunc, Loughborough, UK) 96-well plates were coated with RBD protein (recombinantly generated in a mammalian expression system, in house) at $2 \mu \mathrm{g} / \mathrm{ml}$ in bicarbonate buffer, $\mathrm{pH} 9.6$ at $4^{\circ} \mathrm{C}$ overnight; wells were blocked for 1 hour at room temperature with 3\% w/v non-fat dried milk powder (Sigma Aldrich, \# 70166$500 \mathrm{G}$ ) in phosphate-buffered saline containing 0.1\% Tween 20 (PBS-T), washed in PBS-T. Dilutions of patient sera (1 in 50 in 1\% Milk PBS-T), were added in duplicate to wells coated with RBD protein and incubated for 2 hours at room temperature. Wells were washed three times with PBS-T then incubated (1 hour, room temperature) with secondary antibody (donkey anti-human IgG $\mathrm{F}(\mathrm{ab})_{2}$-horseradish peroxidase (HRP); \#709-036-149, Jackson ImmunoResearch, Ely, UK) for 1 hour at room temperature. After washing (x3), plates were developed using O-phenylenediamine dihydrochloride (OPD, SIGMAFASTTM; Sigma-Aldrich, \# P9187-50SET) and the optical density (OD) measured at $492 \mathrm{~nm}$. Assay validation, including intra-/inter-assay CVs for this assay have been previously described $(17,19)$.

\section{Cytokine Detection}

IFN- $\gamma$ was measured using the IFN- $\gamma$ ELISA MAX Deluxe kit (BioLegend) and performed according to manufacturer's instructions. Microplates were read at $450 \mathrm{~nm}$ immediately following the addition of stop solution $\left(2 \mathrm{~N} \mathrm{H}_{2} \mathrm{SO}_{4}\right)$. IFN- $\gamma$ was quantified by extrapolating from the standard curve using Graphpad Prism. Values below the lower limit of detection of the assay were recorded as $7.81 \mathrm{pg} / \mathrm{ml}$. IL-2 was measured using a custom Bio-Plex Pro Human Cytokine Set (Bio-Rad) and performed according 
medRxiv preprint doi: https://doi.org/10.1101/2021.06.02.21258218; this version posted June 3, 2021. The copyright holder for this preprint

to manufacturer's instructions. The mean fluorescent intensity of the cytokine beads was measured on a Bio-Plex 200 (Bio-Rad). Cytokine concentration was calculated from control curves of standards provided in the kit. Values below the lower limit of detection of the assay were recorded as $6.28 \mathrm{pg} / \mathrm{ml}$.

\section{Statistics}

GraphPad Prism Version 9 was used for all statistical analyses of datasets. Dataset normality was tested using the Shapiro-Wilk test. Significance was determined using either Kruskal-Wallis tests with corrections for multiple comparisons made using the Dunn test, or Mann-Whitney tests, as indicated in the figure legends. Correlation analyses were performed using linear regression. All tests were performed two-sided with a nominal significance threshold of $P<0.05$. 
medRxiv preprint doi: https://doi.org/10.1101/2021.06.02.21258218; this version posted June 3, 2021. The copyright holder for this preprint (which was not certified by peer review) is the author/funder, who has granted medRxiv a license to display the preprint in perpetuity. It is made available under a CC-BY-NC-ND 4.0 International license.

\section{Results}

Prior analysis of the SARS-CoV-2-specific $\mathrm{T}$ cell cytokine profile, measured in supernatants of ex vivo peptide-stimulated ELISpot cultures or whole blood assays, revealed that $\mathrm{T}_{\mathrm{H} 1-t y p e} \mathrm{IFN}-\gamma^{+}$and $\mathrm{IL}-2^{+}$responses dominate effective, functional SARS-CoV-2-specific T cell responses $(5,10)$. The magnitude of TH1-type responses generated to the SARS-CoV-2 S-/NP-/M-combined peptide pool was assessed amongst healthy donor participants who had either received a prior vaccination $(\mathrm{n}=$ 52), a confirmed prior infection $(n=15)$ (PCR positive swab from nasopharynx or saliva sample and/or a strong history of infection with positive measured antibody responses to SARS-CoV-2) or no known history of infection $(n=88)$. Highly significant differential IFN- $\gamma$-positive and IL-2-positive SARS-CoV-2-specific $T$ cell responses were seen amongst vaccinated or previously infected (non-vaccinated) COVID-19-positive individuals in comparison to unknown/naïve individuals (Figure $1 \mathrm{~A} ; \mathrm{P}<0.0001$ and Figure $1 \mathrm{~B} ; \mathrm{P}<0.0001$, respectively). There was no significant difference in the magnitude of IFN- $\gamma$ or IL-2 production between vaccinated and infected participants (Figure 1A and 1B, respectively). Amongst all vaccinated, infected or unknown/naïve participants, there were highly significant correlations between IFN- $\gamma$ and IL-2 production, despite a propensity for increased (>20 pg/ml) IFN- $\gamma^{+}$SARS-CoV-2specific T cell responses without a measurable IL-2 response amongst unknown/naïve donors (Figure 1C).

Next, we correlated participant $T$ cell responses with anti-SARS-CoV-2 RBD lgG antibodies. There was a strong concordance, albeit not significant correlation, between the presence of both cellular and humoral immune responses in all vaccinated and previously infected participants: only 1/15 (6.7\%) previously infected participant had a positive antibody response $(>0.27)$ without a measurable IFN- $\gamma^{+}$or IL-2+ T cell response. All 52 vaccinated participants demonstrated a measurable IFN$\gamma^{+}$or IL-2+ T cell response, although two were antibody negative $(<0.27)$ (Figures 1D and $1 \mathrm{E})$. To investigate whether the increased $\mathrm{T}$ cell responses observed amongst naïve/unknown participants with no history of confirmed infection was indicative of asymptomatic SARS-CoV-2 infection, we further compared the magnitude of IFN- $\gamma^{+}$or $\mathrm{IL}-2^{+} \mathrm{T}$ cell responses with evidence of antibody seroconversion; a significant correlation between T cell response and the magnitude of anti-SARS-CoV-2 RBD IgG antibodies was noted for unknown/naïve participants (IFN- $\gamma$ : $P=0.0002$, Figure 1D; 
medRxiv preprint doi: https://doi.org/10.1101/2021.06.02.21258218; this version posted June 3, 2021. The copyright holder for this preprint

IL-2: $P=0.0010$, Figure $1 E)$. Ten such participants were identified as having both a positive antibody response (>0.27) and raised (above median) IFN- $\gamma^{+}$T cell response, as indicated (Figure 1D), and eight participants also had a positive antibody and increased IL-2 ${ }^{+} \mathrm{T}$ cell response (Figure 1E), consistent with the adaptive immune responses generated in the majority of vaccinated or previously infected participants. Given these participants self-reported no prior confirmed COVID-19 test or symptoms associated with COVID-19 during the pandemic, the presence of both a SARS-CoV2-specific $\mathrm{T}$ cell and antibody response is highly indicative of prior asymptomatic infection.

When assessing the utility of measuring SARS-CoV-2-specific T cell responses to identify those who have received prior COVID-19 vaccination and/or been previously infected, Youden's index revealed an optimal cut-off value of $>23.55 \mathrm{pg} / \mathrm{ml}$ IFN- $\gamma$, achieving a sensitivity of $93.59 \%$ (95\% Cl 85.9-97.2\%) and specificity of $80.8 \%$ $(95 \% \mathrm{Cl} 70.7-88.0 \%)(\mathrm{AUC}=0.94(95 \% \mathrm{Cl} 0.91-0.98) ; \mathrm{P}<0.0001 ;$ Figure $1 \mathrm{~F})$. Measuring IL-2+ $\mathrm{T}$ cell response as the readout adjusted the sensitivity and specificity to $96.0 \%(95 \% \mathrm{Cl} 88.8-98.9 \%)$ and $93.9 \%$ (95\% Cl 86.5-97.4\%), respectively, at an optimal cut-off value of $>20.17 \mathrm{pg} / \mathrm{ml} \mathrm{IL-2}(\mathrm{AUC}=0.96$ (95\% Cl 0.93-1.00); $\mathrm{P}<0.0001$; Figure 1G).

Next, we further evaluated eleven non-vaccinated COVID-19-positive convalescent participants reporting mild to moderate severity of associated symptoms, and ten non-vaccinated participants reporting no prior associated symptoms and for whom both IFN- $\gamma$ and IL-2 data was available (Figure 2A), to determine the functionality of SARS-CoV-2-specific T cells induced by prior asymptomatic infection. The magnitude of IFN- $\gamma$ production was reduced in asymptomatic participants $(P=$ 0.061, Figure $2 \mathrm{~A}$ and $2 \mathrm{~B}$ ); furthermore, a significant reduction in IL-2 production was noted $\left(P=0.0011\right.$, Figure $2 A$ and $2 C$ ). When assessing all $T_{H} 1$ responses by participant infection and symptom status and using optimal cut-offs defined above to identify positive responses, dual-producing IFN- $\gamma^{+} / \mathrm{IL}-2^{+}$SARS-CoV-2-specific T cell responses were present in 10/11 (90.9\%) of symptomatic participants, reducing to $7 / 10(70.0 \%)$ amongst asymptomatic participants (Figure 2D). Given the diminished nature of the SARS-CoV-2-specific $\mathrm{TH}_{\mathrm{H}}$-type cytokine production in asymptomatic donors, both IFN- $\gamma$ and IL-2 are equally useful readouts when assessing for the presence of $\mathrm{T}$ cell responsiveness. 
medRxiv preprint doi: https://doi.org/10.1101/2021.06.02.21258218; this version posted June 3, 2021. The copyright holder for this preprint (which was not certified by peer review) is the author/funder, who has granted medRxiv a license to display the preprint in perpetuity. It is made available under a CC-BY-NC-ND 4.0 International license .

SARS-CoV-2-specific T cell responses amongst unknown / naïve participants, i.e. those with no measurable anti-SARS-CoV-2 RBD $\lg$ antibodies and no prior confirmed history of infection, were rare, with 3/76 (3.8\%) displaying a dual IFN- $\gamma^{+} /$IL$2^{+}$response and $12 / 76$ (15.8\%) displaying an IFN- $\gamma^{+} / \mathrm{IL}-2^{-}$response. This could be indicative of pre-existing, cross-reactive T cells, or a terminally differentiated effector $\mathrm{T}$ cell response. However, further studies are required to ascertain whether those participants with raised anti-SARS-CoV-2-specific $\mathrm{T}_{\mathrm{H} 1}$ responses without seroconversion have been infected by SARS-CoV-2. Interestingly, this discordant immune response has also been reported when monitoring intra-familial exposure to the virus (20).

Finally, we tracked $\mathrm{T}$ cell and antibody responses pre- and post-single dose SARS-CoV-2 vaccination amongst a cohort of healthy controls and a cohort of cancer patients with solid tumours. Robust priming of SARS-CoV-2-specific T cells was observed amongst healthy controls, with 28/29 (96.6\%) mounting an IFN- $\gamma^{+}$response $>23.55 \mathrm{pg} / \mathrm{ml}$ (Figure 3A) and 20/22 (90.9\%) mounting IL-2+ responses $>20.17 \mathrm{pg} / \mathrm{ml}$ (Figure 3B). In contrast, only $27 / 56$ (48.2\%) and 18/31 (58.1\%) of cancer patients mounted an IFN- $\gamma$ (Figure 3A) or IL-2 (Figure 3B) response following single dose SARS-CoV-2 vaccination, respectively. Furthermore, anti-SARS-CoV-2 RBD IgG antibody responses were also compromised in cancer patients though to a lesser degree than the $T$ cell response, with $42 / 54$ (77.8\%) of cancer patients vs. $27 / 28$ $(96.4 \%)$ of healthy controls reaching the threshold of positivity in our antibody test (Figure 3C). This may reflect a limitation of the whole blood-based SARS-CoV-2 T cell assay in that insufficient numbers of lymphocytes may be present to detect such a response; this may be a particular problem in cancer given that lymphopenia is a common occurrence. However, such a situation is also likely to hamper the induction of long-term T cell memory formation.

Overall, these data highlight the power of measuring SARS-CoV-2-specific T cell responses as a means for identifying prior COVID-19 infection, vaccination efficacy and/or potential future immunity from re-infection status. 
medRxiv preprint doi: https://doi.org/10.1101/2021.06.02.21258218; this version posted June 3, 2021. The copyright holder for this preprint (which was not certified by peer review) is the author/funder, who has granted medRxiv a license to display the preprint in perpetuity. It is made available under a CC-BY-NC-ND 4.0 International license.

\section{Discussion}

This study demonstrates the utility of a high-throughput, standardisable $\mathrm{T}$ cell immunoassay to accurately detect SARS-CoV-2-specific T cell responses. In order to control future outbreaks and identify at-risk individuals, the exact constituents of effective COVID-19 immunity at a population level must be understood. When used alongside measurements of virus-specific antibodies, $\mathrm{T}$ cell response readouts represent a powerful, additional measure of potential immunity from COVID-19, with a higher degree of confidence than either measurement on their own, in particular given the concern on the longevity of measurable antibody responses (21-23). In addition, the FDA's decision to issue emergency use authorisation for a SARS-CoV-2 $T$ cell test highlights the growing acceptance and usefulness of $T$ cell testing for the clinical management of certain patient groups (24).

Here, we show that measuring plasma $T_{H} 1$-type effector cytokines from SARSCoV-2 peptide-stimulated whole blood can accurately detect the presence of a cellular immune response to SARS-CoV-2, distinguishing those who have received prior vaccination and/or infection from uninfected healthy donors with a high degree of sensitivity and, in particular for IL-2, specificity. These results are consistent with comprehensive analyses of the cytokine profile released by SARS-CoV-2-specific T cells measured in whole blood-based assays or ELISpot / cell culture supernatants, which showed that IL-2 and IFN- $\gamma$ are the dominant cytokines $(5,10,25)$. However, the relevance of an IFN- $\gamma$-positive, IL-2-negative SARS-CoV-2-specific T cell response in uninfected donors with respect to long-term immunity requires further investigation.

The peptides used in our immunoassay predominantly stimulate CD4+ ${ }^{+} \mathrm{T}$ cell responses, and cover all major immunodominant regions of the virus, including those in the spike, membrane and nucleocapsid proteins, as recently defined (26). TH1-type responses to these immunogenic regions were detected in the vast majority of convalescent SARS-CoV-2 infected and/or vaccinated individuals, in keeping with prior findings $(26,27)$, although convalescent asymptomatic donors and a minority of naïve individuals demonstrate low-level reactivity. Prior studies have revealed the functionality and magnitude of adaptive immune responses to SARS-CoV-2 were significantly lower in mild cases of COVID-19 in comparison to severe (5), potentially the result of lower viral loads $(27,28)$. In accordance with this, our study revealed that production of IFN- $\gamma$ and IL-2 was lower in COVID-19-convalescent asymptomatic 
medRxiv preprint doi: https://doi.org/10.1101/2021.06.02.21258218; this version posted June 3, 2021. The copyright holder for this preprint (which was not certified by peer review) is the author/funder, who has granted medRxiv a license to display the preprint in perpetuity. It is made available under a CC-BY-NC-ND 4.0 International license .

participants. However, a recent longitudinal analysis of asymptomatic SARS-CoV-2 infection identified an increased, highly functional IFN- $\gamma$ and IL-2 response within 3 months of infection that declined faster than in symptomatic individuals (10). Differences in post-infection sampling times likely account for the discrepancy in associations between SARS-CoV-2-specific T cell responses and COVID-19 symptom severity, given that the majority of our participants were infected $\sim 6$ months prior to blood sampling. However, it is encouraging to note that T cell responses were still present and functional over this timeframe in nearly all SARS-CoV-2-infected convalescent and/or vaccinated participants, even in those up to 12 months postinfection, corresponding well with prior studies describing the longevity of anti-SARSCoV-2 T cell immunity (5). Whether these responses provide immune protection, especially to new emerging mutant variants of the SARS-CoV-2 virus, warrants further investigation in larger prospective cohorts. In addition, further downstream analyses incorporating other coronaviruses and additional antigenic regions are necessary to ascertain whether cross-reactive $\mathrm{T}$ cell responses play a role in SARS-CoV-2 immunity.

Future studies are on-going to evaluate the durability of these measured $\mathrm{T}$ cell responses in our participants, comparing healthy subjects with immunocompromised patients, such as those with cancer. After the first dose of vaccine in cancer patients, a significantly weaker induction of cellular and, to a lesser extent, humoral responses was found, corroborating similar observations in other studies (15). These data provide further support to recent calls for cancer patients to be prioritised for booster vaccines and longer-term immunological monitoring.

In summary, we describe an immunoassay that accurately and rapidly identifies the presence of SARS-CoV-2-specific T cell responses, both helping to elucidate the adaptive immune status of previously infected and/or vaccinated individuals, and diagnosing previously unsuspected past infection. Incorporating qualitative $\mathrm{T}$ cell response data in population immunity studies, or individualised certifications of immunity, could have far reaching implications for government policy on lockdown restrictions, and more effectively assess vaccine efficacy in communities, highlighting the potential requirement for repeat vaccinations where immunity wanes. 
medRxiv preprint doi: https://doi.org/10.1101/2021.06.02.21258218; this version posted June 3, 2021. The copyright holder for this preprint (which was not certified by peer review) is the author/funder, who has granted medRxiv a license to display the preprint in perpetuity.

\section{Funding}

This work was funded by two UKRI COVID-19 National Core Study Immunity programmes ('Coordinating COVID-19 asymptomatic testing programmes in university settings: providing insight on acquired immunity across the student population' (to AnG, LF, MW and ADW), and 'SARS-CoV-2 Optimal Cellular Assays' (to AnG). Additional funding was provided by the MRC, as part of the UK Coronavirus Immunology Consortium (to BPM), and Cancer Research Wales (to MJS, MSS and $A n G)$. AnG is supported by additional grant funding from the Wellcome Trust (grant code 209213/Z/17/Z). AwG is supported by additional grant funding from Cancer Research UK. BPM is supported additional funding by from the UK Dementia Research Institute Cardiff. WMZ is supported by a Health and Care Research Wales Fellowship from the Welsh Government. SEAB is supported by the Wales Cancer Research Centre.

\section{Conflict of Interest}

MJS is a founder of and holds equity in ImmunoServ Ltd. All other authors declare no conflicts of interest.

\section{Acknowledgements}

Biosamples from cancer patients were sourced through the Wales Cancer Bank (DOI: http://doi.org/10.5334/ojb.46) which is funded by Health and Care Research Wales. Other investigators may have received specimens from the same subjects. Our thanks are extended to all participants in this study. 
medRxiv preprint doi: https://doi.org/10.1101/2021.06.02.21258218; this version posted June 3, 2021. The copyright holder for this preprint (which was not certified by peer review) is the author/funder, who has granted medRxiv a license to display the preprint in perpetuity. It is made available under a CC-BY-NC-ND 4.0 International license.

\section{References}

1. Grifoni A, Weiskopf D, Ramirez SI, Mateus J, Dan JM, Moderbacher CR, et al. Targets of T Cell Responses to SARS-CoV-2 Coronavirus in Humans with COVID-19 Disease and Unexposed Individuals. Cell. 2020;181(7):1489-501.e15.

2. Sette A, and Crotty S. Pre-existing immunity to SARS-CoV-2: the knowns and unknowns. Nat Rev Immunol. 2020;20(8):457-8.

3. Riou C, Schäfer G, du Bruyn E, Goliath RT, Stek C, Mou H, et al. Rapid, simplified whole blood-based multiparameter assay to quantify and phenotype SARSCoV-2 specific T cells. medRxiv. 2020. doi: 10.1101/2020.10.30.20223099

4. Le Bert N, Tan AT, Kunasegaran K, Tham CYL, Hafezi M, Chia A, et al. SARS-CoV2-specific T cell immunity in cases of COVID-19 and SARS, and uninfected controls. Nature. 2020;584(7821):457-62.

5. Zuo J, Dowell AC, Pearce H, Verma K, Long HM, Begum J, et al. Robust SARS-CoV2-specific T cell immunity is maintained at 6 months following primary infection. Nat Immunol. 2021;22(5):620-6.

6. Wyllie D, Mulchandani R, Jones HE, Taylor-Phillips S, Brooks T, Charlett A, et al. SARS-CoV-2 responsive $T$ cell numbers are associated with protection from COVID-19: A prospective cohort study in keyworkers. medRxiv. 2020. doi: 10.1101/2020.11.02.20222778

7. Diel R, Goletti D, Ferrara G, Bothamley G, Cirillo D, Kampmann B, et al. Interferon-y release assays for the diagnosis of latent Mycobacterium tuberculosis infection: a systematic review and meta-analysis. Eur Respir J. 2011;37(1):88-99.

8. Murugesan K, Jagannathan P, Pham TD, Pandey S, Bonilla HF, Jacobson K, et al. Interferon-gamma release assay for accurate detection of SARS-CoV-2 $\mathrm{T}$ cell response. Clin Infect Dis. 2020. doi: 10.1093/cid/ciaa1537

9. Petrone L, Petruccioli E, Vanini V, Cuzzi G, Najafi Fard S, Alonzi T, et al. A whole blood test to measure SARS-CoV-2-specific response in COVID-19 patients. Clin Microbiol Infect. 2020;22(2):P286.E7-286.E13.

10. Le Bert N, Clapham HE, Tan AT, Chia WN, Tham CYL, Lim JM, et al. Highly functional virus-specific cellular immune response in asymptomatic SARS-CoV-2 infection. J Exp Med. 2021;218(5).

11. Trecarichi EM, Mazzitelli M, Serapide F, Pelle MC, Tassone B, Arrighi E, et al. Clinical characteristics and predictors of mortality associated with COVID-19 in elderly patients from a long-term care facility. Sci Rep. 2020;10(1):20834.

12. Akbar AN, and Gilroy DW. Aging immunity may exacerbate COVID-19. Science. 2020;369(6501):256-7.

13. Sobolev O, Binda E, O'Farrell S, Lorenc A, Pradines J, Huang Y, et al. Adjuvanted influenza-H1N1 vaccination reveals lymphoid signatures of age-dependent early responses and of clinical adverse events. Nat Immunol. 2016;17(2):204-13.

14. Shehata MA, and Karim NA. Influenza vaccination in cancer patients undergoing systemic therapy. Clin Med Insights Oncol. 2014;8:57-64. 

medRxiv preprint doi: https://doi.org/10.1101/2021.06.02.21258218; this version posted June 3,2021 . The copyright holder for this preprint
(which was not certified by peer review) is the author/funder, who has granted medRxiv a license to display the preprint in perpetuity. It is made available under a CC-BY-NC-ND 4.0 International license

15. Monin L, Laing AG, Muñoz-Ruiz M, McKenzie DR, del Molino del Barrio I, Alaguthurai $\mathrm{T}$, et al. Safety and immunogenicity of one versus two doses of the COVID-19 vaccine BNT162b2 for patients with cancer: interim analysis of a prospective observational study. Lancet Oncology. 2021;S1470-2045(21)00213-8.

16. Amanat F, Stadlbauer D, Strohmeier S, Nguyen THO, Chromikova V, McMahon M, et al. A serological assay to detect SARS-CoV-2 seroconversion in humans. Nat Med. 2020;26(7):1033-6.

17. Stadlbauer D, Amanat F, Chromikova V, Jiang K, Strohmeier S, Arunkumar GA, et al. SARS-CoV-2 Seroconversion in Humans: A Detailed Protocol for a Serological Assay, Antigen Production, and Test Setup. Curr Protoc Microbiol. 2020;57(1):e100.

18. Moat SJ, Zelek WM, Carne E, Ponsford MJ, Bramhall K, Jones S, et al. Development of a high-throughput SARS-CoV-2 antibody testing pathway using dried blood spot specimens. Ann Clin Biochem. 2020:4563220981106.

19. Murrell I, Forde D, Zelek W, Tyson L, Chichester L, Palmer N, et al. Temporal development and neutralising potential of antibodies against SARS-CoV-2 in hospitalised COVID-19 patients: An observational cohort study. PLoS One. 2021;16(1):e0245382.

20. Gallais F, Velay A, Nazon C, Wendling M-J, Partisani M, Sibilia J, et al. Intrafamilial Exposure to SARS-CoV-2 Associated with Cellular Immune Response without Seroconversion, France. Emerging Infectious Diseases. 2021;27(1):10.3201/eid2701.203611.

21. Ward H, Cooke G, Atchison C, Whitaker M, Elliott J, Moshe M, et al. Declining prevalence of antibody positivity to SARS-CoV-2: a community study of 365,000 adults. medRxiv. 2020. doi: 10.1101/2020.10.26.20219725

22. Mulchandani R, Jones HE, Taylor-Phillips S, Shute J, Perry K, Jamarani S, et al. Accuracy of UK Rapid Test Consortium (UK-RTC) "AbC-19 Rapid Test" for detection of previous SARS-CoV-2 infection in key workers: test accuracy study. BMJ. 2020;371:m4262.

23. Bilich T, Nelde A, Heitmann JS, Maringer Y, Roerden M, Bauer J, et al. T cell and antibody kinetics delineate SARS-CoV-2 peptides mediating long-term immune responses in COVID-19 convalescent individuals. Sci Transl Med. 2021;13(590).

24. Dalai SC, Dines JN, Snyder TM, Gittelman RM, Eerkes T, Vaney P, et al. Clinical Validation of a Novel T-cell Receptor Sequencing Assay for Identification of Recent or Prior SARS-CoV-2 Infection. medRxiv. 2021. doi: 10.1101/2021.01.06.21249345

25. Weiskopf D, Schmitz KS, Raadsen MP, Grifoni A, Okba NMA, Endeman H, et al. Phenotype and kinetics of SARS-CoV-2-specific T cells in COVID-19 patients with acute respiratory distress syndrome. Sci Immunol. 2020;5(48).

26. Tarke A, Sidney J, Kidd CK, Dan JM, Ramirez SI, Yu ED, et al. Comprehensive analysis of T cell immunodominance and immunoprevalence of SARS-CoV-2 epitopes in COVID-19 cases. Cell Rep Med. 2021:100204. 
medRxiv preprint doi: https://doi.org/10.1101/2021.06.02.21258218; this version posted June 3, 2021. The copyright holder for this preprint

(which was not certified by peer review) is the author/funder, who has granted medRxiv a license to display the preprint in perpetuity. It is made available under a CC-BY-NC-ND 4.0 International license.

27. Peng Y, Mentzer AJ, Liu G, Yao X, Yin Z, Dong D, et al. Broad and strong memory $\mathrm{CD}^{+}$and $\mathrm{CD}^{+} \mathrm{T}$ cells induced by SARS-CoV-2 in UK convalescent individuals following COVID-19. Nat Immunol. 2020;21(11):1336-45.

28. Wang Y, Zhang L, Sang L, Ye F, Ruan S, Zhong B, et al. Kinetics of viral load and antibody response in relation to COVID-19 severity. J Clin Invest. 2020;130(10):523544. 

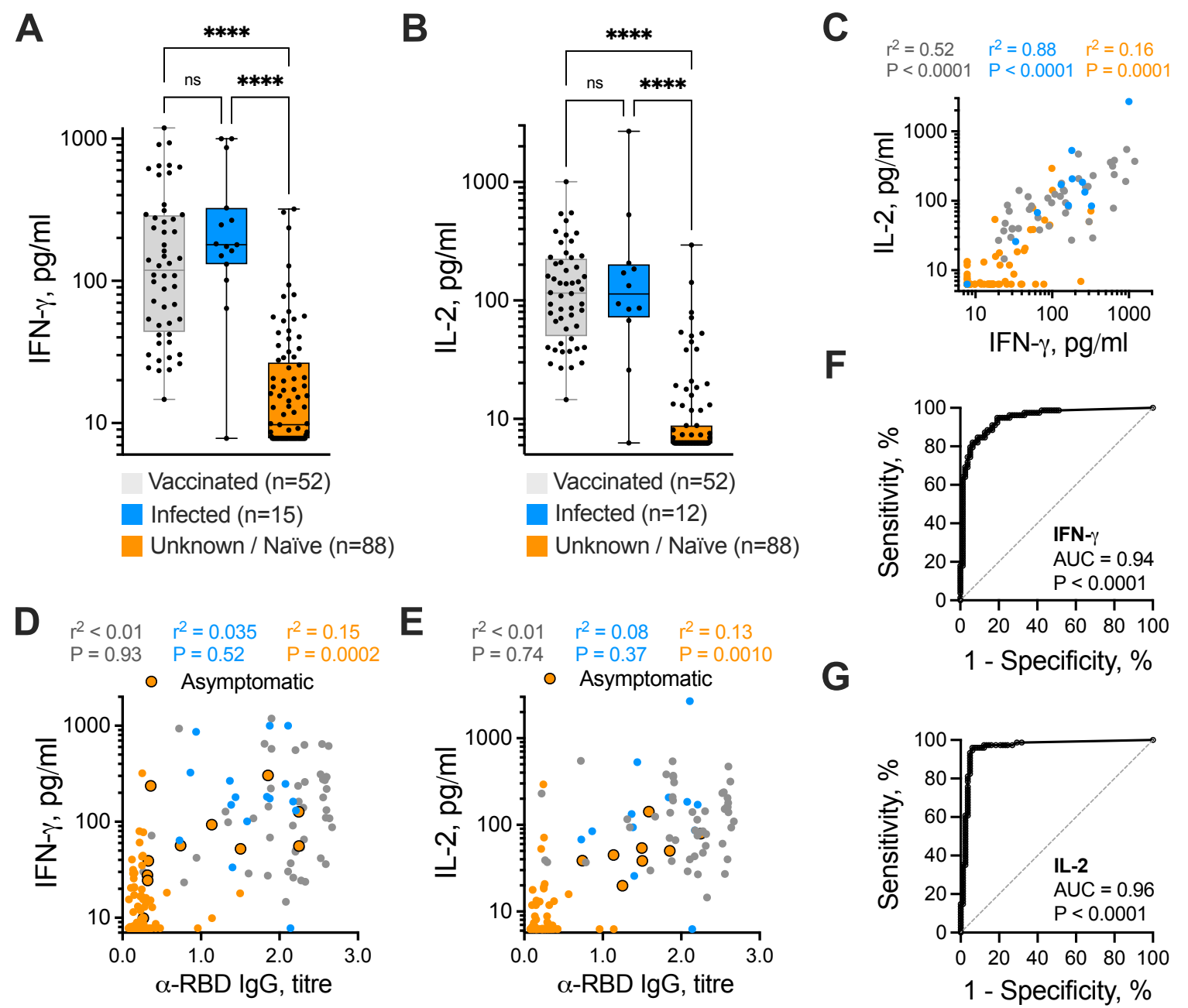

Figure 1. SARS-CoV-2-specific $T$ cell response identifies prior asymptomatic infection. IFN- $\gamma(A)$ and IL-2 (B) release in response to the SARS-CoV-2 S-/NP-/Mcombined peptide pool was measured in 156 evaluable participants, subdivided into those with prior COVID-19 vaccination (grey, $n=52$ ), prior COVID-19-positive PCR test result (blue, $n=12-15$ ), or those with no prior positive COVID-19 test, termed 'unknown/naïve' (orange, $\mathrm{n}=88$ ). Statistical analyses indicate the results of a Kruskal-Wallis test with Dunn's correction for multiple comparisons ( ${ }^{* * * *} P<0.0001$ ).

(C) The SARS-CoV-2-specific IL-2+ T cell response was correlated with the IFN- $\gamma^{+}$ response, subdivided by participant status. The anti-SARS-CoV-2 RBD IgG antibody titre was correlated with the magnitude of IFN- $\gamma^{+} T$ cell response (D) and IL-2+ $\mathrm{T}$ cell response $(E)$, with identified asymptomatic participants highlighted. Results of regression analyses are indicated. Sensitivity and specificity readouts for IFN- $\gamma(F)$ and IL-2 $(G)$ were defined by receiver operating characteristic curves. Area under the curve (AUC) and associated $P$ value are indicated. 


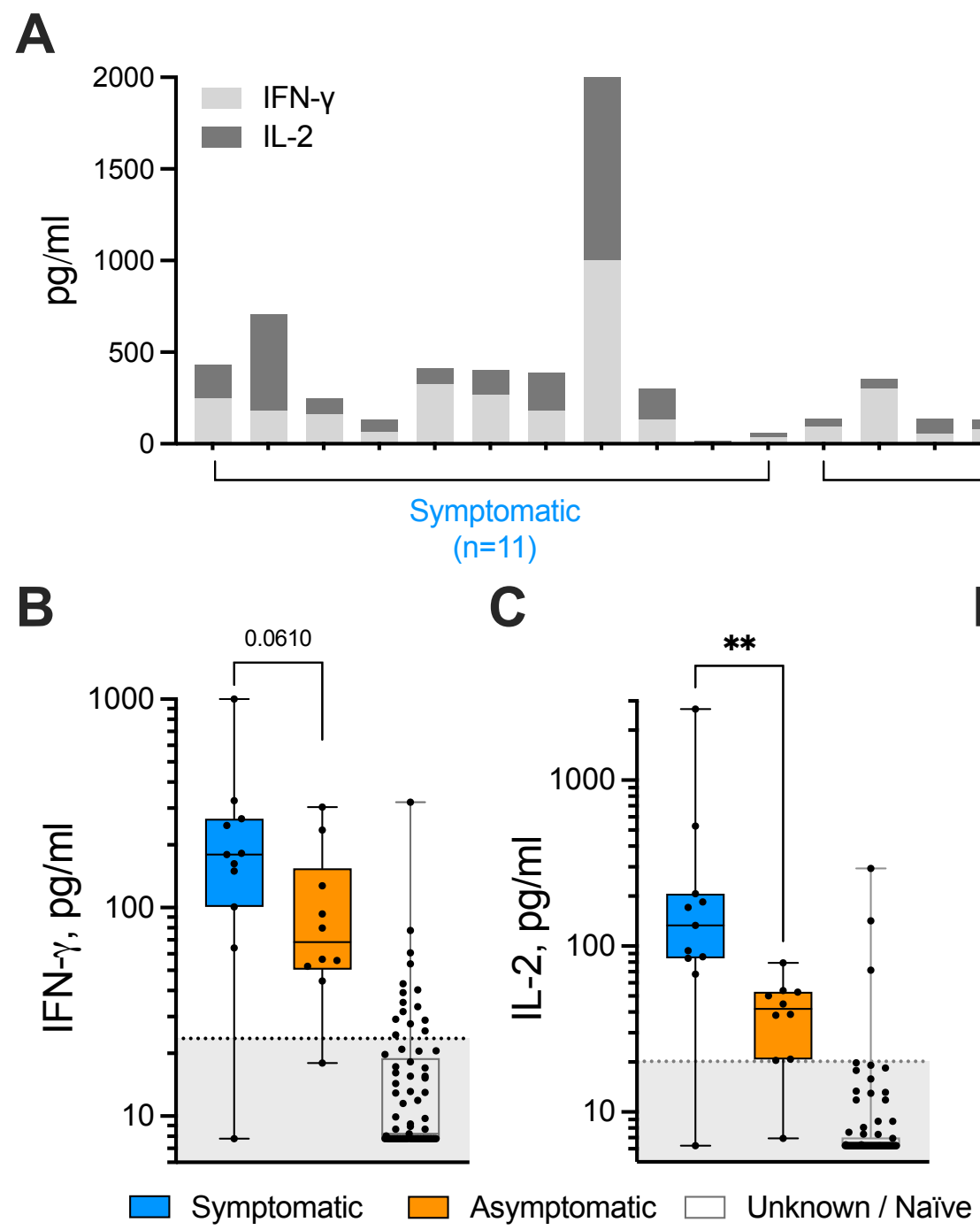

Asymptomatic $(n=10)$

B

D IFN-ץ IL-2-

IFN-Y IL-2 +

IFN- $\gamma^{+}$IL-2-

IFN- $\gamma^{+} \mathrm{IL}-2^{+}$

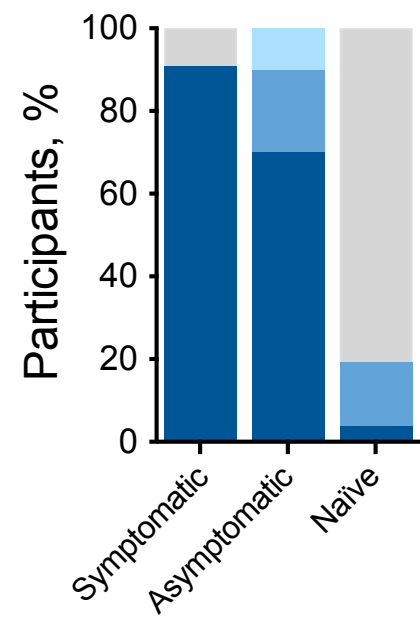

Figure 2. Asymptomatic participants exhibit reduced SARS-CoV-2-specific T cell functionality. (A) IFN- $\gamma$ and IL-2 T cell responses amongst eleven symptomatic and 10 asymptomatic SARS-CoV-2-infected donors is shown for each individual. IFN- $\gamma(B)$ and IL-2 (C) release by T cells in response to the SARS-CoV-2 S-/NP-/Mcombined peptide pool was measured in the symptomatic, asymptomatic and naïve donors $(n=76)$. $P$ values resulting from Mann Whitney tests are shown $\left({ }^{\star \star} P<0.01\right)$. The proportion of symptomatic, asymptomatic and naïve participants mounting dual IFN- $\gamma^{+} / \mathrm{IL}-2^{+}$, single IFN- $\gamma$ or IL-2+ or no measurable T cell response is shown (D). 
medRxiv preprint doi: https://doi.org/10.1101/2021.06.02.21258218; this version posted June 3, 2021. The copyright holder for this preprint (which was not certified by peer review) is the author/funder, who has granted medRxiv a license to display the preprint in perpetuity.

A

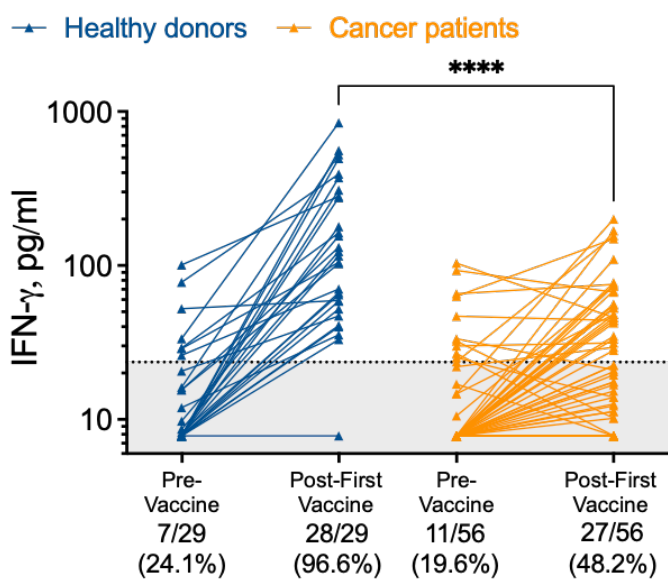

C

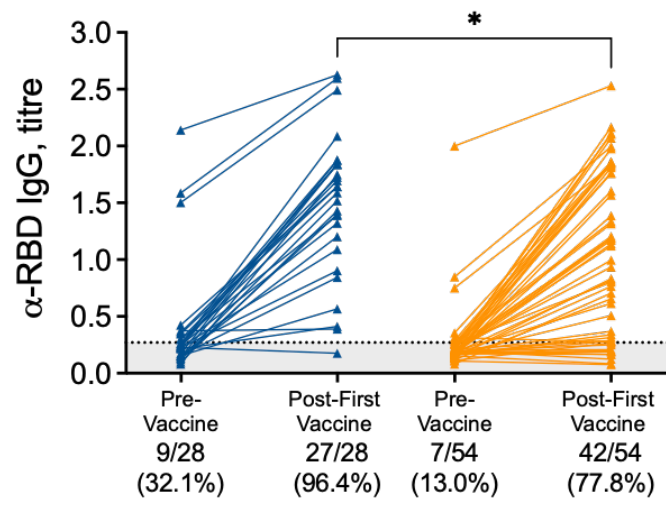

B

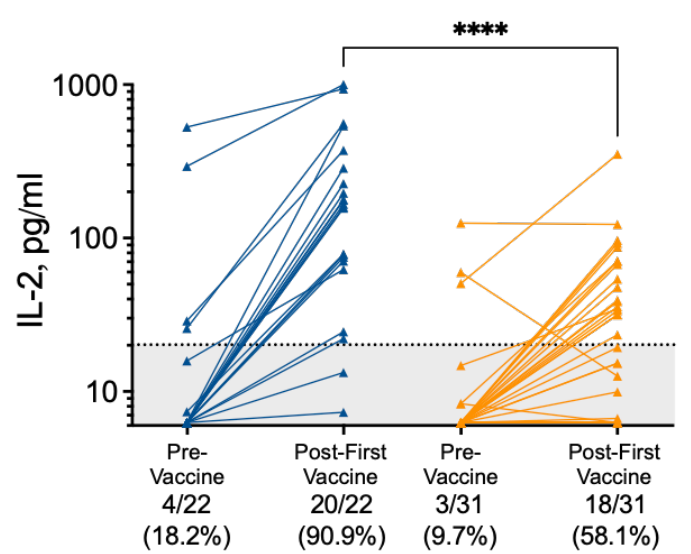

D

\begin{tabular}{llccl} 
Analyte & Cohort & NR & $\mathrm{R}$ & Fisher's Test \\
\hline \multirow{2}{*}{ IFN- $\gamma$} & Healthy donors & 1 & 28 & $* * *$ \\
& Cancer patients & 19 & 27 & $\mathrm{P}=0.0003$ \\
\hline \multirow{2}{*}{ IL-2 } & Healthy donors & 2 & 20 & $*$ \\
& Cancer patients & 13 & 18 & $\mathrm{P}=0.0127$ \\
\hline \multirow{2}{*}{ IgG } & Healthy donors & 1 & 27 & $*$ \\
& Cancer patients & 12 & 42 & $\mathrm{P}=0.0297$ \\
\hline
\end{tabular}

Figure 3. Utilising SARS-CoV-2-specific $T$ cell response measurements as a readout for COVID-19 vaccine efficacy amongst healthy donor and cancer patient cohorts. IFN- $\gamma^{+}(\mathrm{A})$ and IL-2+ $(\mathrm{B}) \mathrm{SARS}-\mathrm{CoV}$-2-specific T cell responses and anti-SARS-CoV-2 RBD IgG levels $(C)$ were measured before and 3-6 weeks after a single COVID-19 vaccination in healthy donors and cancer patients. Two-tailed $P$ values resulting from Mann Whitney tests are shown. (D) Vaccination response rates ( $N R=$ no response, $R=$ response) in terms of positive $T$ cell (IFN- $\gamma$, IL-2) or antibody (RBD $\operatorname{lgG}$ ) response amongst each cohort is shown. $P$ values indicate results from Fisher's exact test. 
medRxiv preprint doi: https://doi.org/10.1101/2021.06.02.21258218; this version posted June 3, 2021. The copyright holder for this preprint (which was not certified by peer review) is the author/funder, who has granted medRxiv a license to display the preprint in perpetuity. It is made available under a CC-BY-NC-ND 4.0 International license .

Table 1. Basic participant characteristics

\begin{tabular}{|l|l|l|}
\hline & $\begin{array}{l}\text { Cancer } \\
\text { patients }(\mathbf{n}=68)\end{array}$ & $\begin{array}{l}\text { Healthy donors } \\
(\mathbf{n = 1 5 6})\end{array}$ \\
\hline Mean age, years (range) & $52.6(28-79)$ & $35.6(18-81)$ \\
\hline Sex & & \\
\hline Male & $25 / 68(36.8 \%)$ & $48 / 156(30.8 \%)$ \\
\hline Female & $43 / 68(63.3 \%)$ & $108 / 156(69.2 \%)$ \\
\hline
\end{tabular}

